\title{
Brand Experience, Brand Commitment, and Brand Loyalty of Xiaomi Smartphone Users in Magelang
}

\author{
Galuh Tiyasherlinda ${ }^{1)}$, Ivo Novitaningtyas ${ }^{2)}$ \\ 1), 2) Universitas Tidar, Indonesia \\ Email: galuhtias36@gmail.com ${ }^{l)}$,ivo.novitaningtyas@untidar.ac.id ${ }^{2}$
}

\begin{abstract}
Increasingly technological developments and the increasing use of smartphones have led to competition between brands. Every smartphone company always innovates to meet the needs and desires of consumers, so that consumers will remain in one brand. The purpose of this study is to determine the effect of Brand Experience and Brand Commitment on Brand Loyalty of Xiaomi smartphone users, especially in the Magelang. This study uses a quantitative approach by distributing questionnaires to 100 respondents as a sample to obtain primary data. The sampling method used purposive sampling with the consideration that the respondents met the criteria, such as living in Magelang and currently using a Xiaomi smartphone. Multiple linear regression analysis with SPSS version 25 software was used as a data analysis technique. The results showed that Brand Experience had a positive effect but not significant on Brand Loyalty, while Brand Commitment had a positive and significant effect on Brand Loyalty. The results provide managerial implications for smartphone companies to provide brand experiences to users and increase user brand commitment to increase user loyalty to brands.
\end{abstract}

Keywords: brand experience, brand commitment, brand loyalty, smartphone

\section{Introduction}

The development of technology is increasingly complex and has many impacts on people's lives. The impact of these technological developments includes making it easy for long-distance communication, obtaining information, and providing convenience in carrying out activities. One of the most common technological developments is the smartphone. Currently, smartphones are very important items for the community to have because almost all community activities require smartphone-based technology. This condition causes market demand for smartphones to continue to increase and leads to competition between smartphone manufacturers.

In Indonesia, the number of smartphone users is estimated to always increase when viewed from statistical data, namely by $47.4 \%$ from 2015 to 2021 . With so many smartphone brands available, consumers will be more selective in choosing the smartphone brand they need. Therefore, smartphone companies must be able to innovate so that consumers feel satisfied with the product they choose and can leave a good impression. Thus, consumers remain loyal to the brand.

One of the smartphone brands in Indonesian market is Xiaomi. Xiaomi Technology Co., Ltd is a private electronics company from China, headquartered in Beijing. The company was founded in 2010 and today has become a world-leading brand. In the face of market competition, Xiaomi strives to continue to innovate and create experiences for users from various aspects ranging from design, features to price in order to give a good impression to consumers. A good experience from a brand can make a brand experience for consumers and make it possible to use or repurchase the brand compared to competing brands (Brakus et al., 2009).

In marketing, brand loyalty is an important aspect of brand equity (Hermaren \& Achyar, 2018). 
Loyalty can be used as a measure related to customer loyalty to a brand. When brand loyalty increases, it minimizes the possibility for customers to switch to competing products. If a brand can meet consumer expectations, then consumers will trust the brand and stay with the brand (Pratiwi et al., 2015). Therefore, if Xiaomi wants to reduce its competitors, Xiaomi must pay attention to user loyalty.

Brand experience defines as a feeling, reaction or experience produced by a brand (Yobeanto, 2020). If the experience is well managed it can be a competitive advantage for the brand. When Xiaomi can give consumers a positive impression and experience and is consistent with the services provided, consumers will be interested in these products and will feel satisfied. Thus, it is hoped that it can foster consumers' desire to repurchase the brand. This means that consumer experience affects brand loyalty and if producers want consumers to remain loyal to their brands, producers must be able to meet consumer satisfaction and consumer expectations.

According to Junita (2013), brand commitment relates to the ongoing relationship between brands and consumers. Commitment is a very important asset for companies to establish longterm and beneficial relationships with each other, or it can be said that commitment is closely related to consumer loyalty. Commitment to a brand will arise when consumers believe and believe in their choices and think that the brand is part of themselves. Therefore, if Xiaomi wants consumers to commit to its brand, Xiaomi must be able to convince consumers through customer service and satisfaction.

Previous research states that brand experience and brand commitment have a positive effect on brand loyalty (Ubud \& Ubud, 2016; Yobeanto, 2020). Even though, Semuel \& Putra (2018) states that brand experience has no direct influence on brand loyalty. This shows a gap from the results of previous studies. Thus, further research is needed which aims to review how brand experience and brand commitment influence the brand loyalty of Xiaomi smartphone users. The results of the research are expected to be able to support the results of previous research and become a reference for future researchers. In addition, the research results also provide managerial implications for Xiaomi to consider brand experience and brand commitment in developing a strategy to increase user loyalty.

\section{Literature Review}

\subsection{Brand Experience}

Brand experience is a feeling, consumer response, or experience caused by a brand. Brand experience arises when consumers search for a product, buy, receive and consume products from a brand (Semuel \& Putra, 2018). According to Rahmat \& Marso (2020) if the consumer experience is managed properly, it will be able to create a competitive advantage for the company and have a positive impact on the brand. In addition, the brand experience that is inherent in consumers can be one of the factors that underlie the existence of consumer satisfaction and loyalty to the brand. From several previous studies, it is stated that brand experience has a significant positive effect on brand loyalty (Pujiyanti, 2018; Suntoro \& Silintowe, 2020). However, Semuel \& Putra (2018) states that brand experience does not have a significant effect on brand loyalty. For this reason, this study will review the effect of brand experience on brand loyalty, especially for Xiaomi smartphone users in Magelang. Moreover, according to Brakus et al., (2009), brand experience has 4 dimensions, such as: (1) Sensory in the form of experiences obtained through sensory organs, (2) Affection in the form of feelings that can affect moods and emotions, (3) Behavior is an experience obtained physically, behavior and lifestyle, and (4) Intellectual is an experience that involves thinking about the existence of

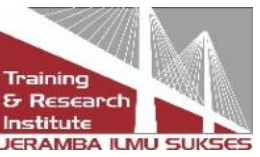


a brand.

\subsection{Brand Commitment}

Brand commitment defines as a sensation or response generated by brand-related stimuli which is part of the brand's communication design, the environment, the experience of buying, receiving services, and consuming or using products (Brakus et al., 2009). According to Arief et al., (2017) states that brand commitment has 2 contexts, namely affective commitment and continuance commitment. Affective commitment explains consumer emotions towards a brand, consumer recognition of the brand, and consumer participation in the brand. Meanwhile, continuance commitment explains consumer perceptions regarding the costs and risks faced when switching from a brand or can be said to look more at price changes and existing alternatives.

A high consumer commitment to a brand shows that consumers trust the brand and allow for repeat purchases (Khodabandeh \& Lindh, 2020). This confirms that brand commitment has an influence on consumer loyalty. Moreover, Semuel \& Putra (2018) also states that brand commitment does not have a significant effect, but indirectly affective commitment has a significant effect on brand loyalty. Thus, this study will re-examine whether brand commitment has a strong influence or not on consumer loyalty, especially for Xiaomi smartphone users in Magelang.

\subsection{Brand Commitment}

Brand loyalty defines as a consumer attitude that shows a commitment to a product or brand by making repeat purchases in the future even though there are situational or marketing influences that can result in transitional behavior (Firmansyah, 2019). According to Firmansyah (2019) states that brand loyalty has several indicators, including the following: (1) Having a commitment to the brand, (2) Willing to pay whatever for the brand, (3) Suggesting brands to others, (4) When repurchasing products do not reconsider, (5) Follow the information related to the brand, and (6) Maintain a good relationship with the brand and can be like a spokesperson for the brand.

\section{Research Method}

This study uses a quantitative approach. Quantitative research is used to examine certain samples in the population through research instruments in collecting data, and data analysis is carried out using quantitative statistics to test the hypothesis (Sugiyono, 2013). The research design is a causal design to understand the causal relationship or causality of the variables studied (Suhartanto, 2014). The research was conducted for 3 months, from February to April 2021. This research was conducted in the Magelang area. The population in this study were all residents of the Magelang community who had and are currently using Xiaomi smartphones. As for the number of the population is not limited or not known with certainty, the sample size is determined by 100 respondents. This number is considered to meet the sample size of between 30-500 (Ghozali, 2017). Sampling is done using non-probability sampling methods or sampling is not done randomly, with the consideration that not all members of the population have the opportunity to be sampled (Irmansyah \& Budiarti, 2018). The type of non-probability sampling used is purposive sampling, by determining the following criteria for respondents: 1) respondents aged 15 years old and over, 2) respondents are Magelang people who use Xiaomi smartphones. The type of data used in this study is primary data which is obtained directly from respondents through a questionnaire. The questionnaire used in this study is a closed question 
type where the respondent simply chooses one alternative answer to the question. Likert scale is used to measure respondents' perceptions of the research variable indicators. The questionnaire was distributed to respondents online via Google Form. The data that has been collected then analyzed based on multiple linear regression analysis using SPSS. The hypotheses in this study are (1) Brand experience is thought to have an effect on brand loyalty to Xiaomi smartphone users in Magelang, and (2) Brand commitment is thought to have an effect on brand loyalty to Xiaomi smartphone users in Magelang.

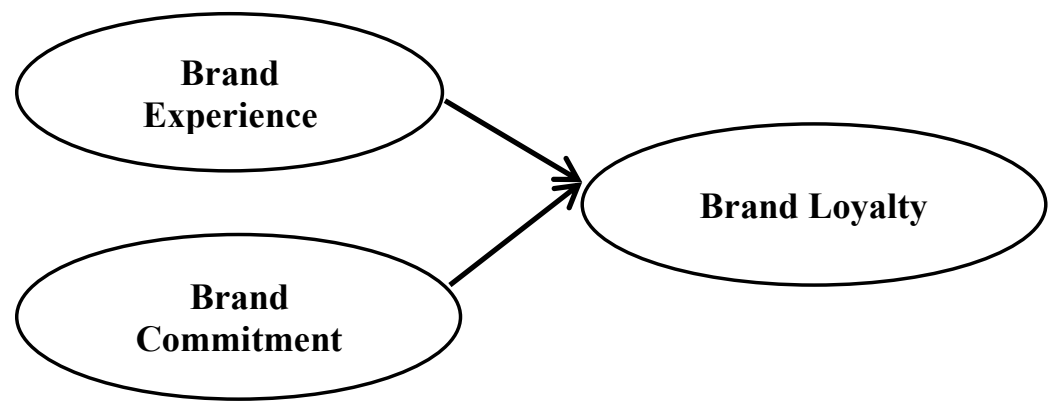

Figure 1. Research Framework

Source: processed by author, 2021

\section{Findings and Discussions}

\subsection{Validity and Reliability Test Result}

Based on the results of the validity test, each research variable, namely Brand Experience, Brand Commitment, and Brand Loyalty, shows that the indicator items of the three variables are valid because they meet the criteria that the calculated $r$-value is greater than the r-table. The number of respondents used was 100 respondents with a significance level of 5\% or 0.196 . This means that if the r-count is more than 0.196 the questionnaire is declared valid. Moreover, the reliability test was conducted using the Cronbach-Alpha analysis. A variable is declared reliable if the Cronbach alpha value exceeds 0.7 (Ghozali, 2011). The results show that all variables are declared reliable.

Table 1. Reliability Test Result

\begin{tabular}{lcl}
\hline Variable & Cronbach's Alpha & Result \\
\hline Brand Experience & 0,880 & Reliable \\
Brand Commitment & 0,913 & Reliable \\
Brand Loyalty & 0,941 & Reliable \\
\hline
\end{tabular}

Source: Data Processed 2021 
Table 2. Validity Test Result

\begin{tabular}{ccccc}
\hline Variable & Item & r-value & r-table & Result \\
\hline Brand Experience & X1.1 & 0,715 & 0,196 & Valid \\
& X1.2 & 0,792 & 0,196 & \\
X1.3 & 0,792 & 0,196 & \\
X1.4 & 0,809 & 0,196 & \\
Brand Commitment & X2.1 & 0,802 & 0,196 & \\
& X2.2 & 0,734 & 0,196 & \\
X2.3 & 0,807 & 0,196 & Valid \\
X2.4 & 0,825 & 0,196 & \\
X2.5 & 0,833 & 0,196 & \\
& Y3.1 & 0,872 & 0,196 & Valid \\
& Y3.2 & 0,875 & 0,196 & \\
& Y3.3 & 0,768 & 0,196 & \\
& Y3.4 & 0,849 & 0,196 & \\
& Y3.5 & 0,818 & 0,196 & \\
& & 0,826 & 0,196 & \\
& &
\end{tabular}

Source: Data Processed 2021

\subsection{Multiple Linear Regression Analysis}

Based on the results of the regression test between the variables Brand Experience, Brand Commitment, and Brand Loyalty, the regression equation can be compiled as follows:

$\mathrm{Y}=-2,399+0,105 \mathrm{X} 1+1,104 \mathrm{X} 2+\mathrm{e}$

From the results of this equation, it can be explained that the Brand Experience regression value is 0.105, meaning that if the Brand Experience variable is getting better, then user loyalty to the brand will also increase by 0.105 if the other variables are constant. Furthermore, Brand Experience is proven to have a positive influence on Brand Loyalty. However, the effect is not significant because the value is 0.614 , which is greater than 0.05 . These results are appropriate to support previous research which states that Brand Experience does not have a significant effect on Brand Loyalty (Semuel \& Putra, 2018).

The regression value of Brand Commitment is 1.104, meaning that if the value of the Brand Commitment variable increases, user loyalty to the brand will also increase by 1.104 if the other 
variables are constant. Furthermore, Brand Commitment is proven to have a positive influence on Brand Loyalty. In addition, the influence of this variable is proven significant because the significance value is 0.000 , which is less than 0.05 . These results support previous research which states that the higher the customer commitment to a brand, it will increase customer loyalty to the brand used (Ubud \& Ubud, 2016). Thus, committed Xiaomi smartphone users will tend to buy Xiaomi products again and recommend to others regarding Xiaomi products.

Table 3. Multiple Linear Regression Results

\begin{tabular}{|c|c|c|c|c|c|c|}
\hline \multirow[b]{2}{*}{ Model } & & \multicolumn{2}{|c|}{ Unstandardized Coefficients } & \multicolumn{2}{|l|}{$\begin{array}{l}\text { Standardized } \\
\text { Coefficients }\end{array}$} & \multirow[b]{2}{*}{ Sig. } \\
\hline & & $\mathrm{B}$ & Std. Error & Beta & $\mathrm{T}$ & \\
\hline \multirow[t]{3}{*}{1} & (Constant) & -2.399 & 1.639 & & -1.464 & .146 \\
\hline & $\mathrm{BE}(\mathrm{X} 1)$ & .105 & .208 & .048 & .506 & .614 \\
\hline & $\mathrm{BC}(\mathrm{X} 2)$ & 1.104 & .136 & .778 & 8.140 & .000 \\
\hline \multicolumn{7}{|c|}{ Adjusted r2 $=0,667$} \\
\hline $\mathrm{F}$ & $=97,117$ & & & & & \\
\hline
\end{tabular}

Furthermore, to test the feasibility of the model, the F-test testing tool was used. This is intended to test the significance of the influence together or simultaneously the sub variables consisting of Brand Experience (X1) and Brand Commitment (X2) on Brand Loyalty (Y). The results of the analysis show that the value of F-value is 97,117 , while F-table at the 0.05 significance level shows a value of 3.09. This means that F-value is greater than F-table. Based on this, it can be said that the better the brand experience and the higher the commitment of consumers or smartphone users to the Xiaomi brand, it will increase consumer or user loyalty to the Xiaomi brand.

Moreover, the purpose of the coefficient of determination analysis is to see the ability of a model to explain the variation in the dependent variable. The results showed that the R-value was 0,000 or it could be seen that there was a strong relationship between variables. The value of Adjusted R-square shows a number of 0.667 or $66.7 \%$. This means that the effect of the independent variable on the dependent variable is $66.7 \%$. While the remaining $33.3 \%$ is influenced by other variables that are not examined in this study or are not included in the research model.

The results become a reference source for future researchers. This research is limited to the use of two independent variables in the research model. Suggestions for further researchers can develop a model by adding other independent variables or adding a mediating variable. In addition, further research can also use other relevant data analysis techniques and conduct research on other smartphone brands in other areas. The results give practically or managerially implication for smartphone companies to provide brand experiences to users and increase user brand commitment to make the user loyal to the brand. Loyal user has a positive impact on the 
company such as recommend product to others and willing to repeat purchase.

\section{Conclusion}

Simultaneous testing of the Brand Loyalty variable which consists of Brand Experience and Brand Commitment variables shows that there is a significant influence simultaneously. Then, the partial test shows the results that the Brand Experience variable has a positive effect on Brand Loyalty but not significant, while Brand Commitment has a positive and significant effect on Brand Loyalty on Xiaomi smartphone users in Magelang. The results of the study provide managerial implications for smartphone manufacturers to be able to provide a good brand experience for users through product features and innovate according to the development trend of user needs for smartphone products. In addition, because Brand Commitment is proven to have a significant effect on Brand Loyalty, smartphone manufacturers also need to increase the commitment from their users to their products and brand. By increasing user commitment, the user will more loyal to the brand. Thus, if smartphone manufacturers have users who are loyal to their brands, it is hoped that users will provide benefits for the company such as being willing to buy new products that are marketed by the company, willing to tell positive things about products to others, and also willing to recommend products to other potential users. The results of this study are also become a reference for further research to develop factors that can increase brand loyalty in smartphone products. Further research can measure the influence of other variables toward brand loyalty of smartphone products, or add a mediating variable in the model. Further research also can develop the data analysis method and conduct research in other smartphone brands.

\section{References}

Arief, M., Suyadi, I., \& Sunarti, S. (2017). PENGARUH KEPERCAYAAN MEREK DAN KOMITMEN MEREK TERHADAP LOYALITAS MEREK (Survei pada Warga Kelurahan Penanggungan Konsumen Produk Aqua di Kota Malang). Jurnal Administrasi Bisnis S1 Universitas Brawijaya, 44(1), 144-153.

Brakus, J. J., Schmitt, B. H., \& Zarantonello, L. (2009). Brand Experience: What Is It? How Is It Measured? Does It Affect Loyalty? Journal of Marketing, 73(3), 52-68. https://doi.org/10.1509/jmkg.73.3.52

Firmansyah, M. A. (2019). Pemasaran Produk dan Merek (Planning \& Strategy). 203. Ghozali, I. (2011). Aplikasi Analisis Multivariate Dengan Program IBM SPSS 19 (edisi kelima). Semarang: Universitas Diponegoro.

Ghozali, I. (2017). Model Persamaan Struktural Konsep dan Aplikasi Dengan Program AMOS 24 Update Bayesian SEM Edisi 7. Semarang: Badan Penerbit Universitas Diponegoro.

Hermaren, V., \& Achyar, A. (2018). The effect of firm created content and user generated content evaluation on customer-based brand equity. INOBIS: Jurnal Inovasi Bisnis Dan Manajemen Indonesia, 2(1), 86-100. https://doi.org/10.31842/jurnal-inobis.v2i1.63

Irmansyah, A. N., \& Budiarti, A. (2018). Pengaruh kualitas produk, citra merek, harga terhadap loyalitas pengguna smartphone xiaomi di surabaya. 1-14.

Khodabandeh, A., \& Lindh, C. (2020). The importance of brands, commitment, and influencers on purchase intent in the context of online relationships. Australasian Marketing Journal, (xxxx). https://doi.org/10.1016/j.ausmj.2020.03.003

Pratiwi, D. M., Saerang, D. P. ., \& Tumewu, F. (2015). The Influence of Brand Image, Brand Trust and Customer Satisfaction on Brand Loyalty (Case of Samsung Smartphone). Jurnal Berkala Ilmiah Efisiensi, 15(5), 377-385. 
Pujiyanti. (2018). Pengaruh Brand Reputation, Brand Experience Terhadap Brand Loyalty Melalui Brand Trust Pada Pengguna Kartu Simpati Loop Di Kota Semarang.

Rahmat, R., \& Marso, M. (2020). Hubungan Brand Experience, Brand Image, Brand Satisfaction, Dan Brand Loyalty Dalam Pespektif Four-Stage Loyalty Model (Studi Terhadap Mahasiswa Pengguna Smartphone Di Tarakan). Jurnal Manajemen Pemasaran, 14(1), 17-24. https://doi.org/10.9744/pemasaran.14.1.17-24

Semuel, H., \& Putra, R. S. (2018). Brand Experience, Brand Commitment, Dan Brand Loyalty Pengguna Apple Iphone Di Surabaya. Jurnal Manajemen Pemasaran, 12(2), 69-76. https://doi.org/10.9744/pemasaran.12.2.69-76

Sugiyono. (2013). Metode Penelitian Bisnis (Pendekatan Kuantitatif, Kualitatif dan R\&D). Bandung: Penerbit Alfabeta.

Suhartanto, D. (2014). Metode Riset Pemasaran. Bandung: Penerbit Alfabeta.

Suntoro, W., \& Silintowe, Y. B. R. (2020). Analisis Pengaruh Pengalaman Merek, Kepercayaan Merek, dan Kepuasan Merek terhadap Loyalitas Merek. Maneggio: Jurnal Ilmiah Magister Manajemen, 32(1), 25-41.

Ubud, S., \& Ubud, S. (2016). Strategi Kualitas Hubungan Merek, Komitmen, Kecintaan Terhadap Loyalitas Merek Pada Restoran Waralaba. MIX: Jurnal Ilmiah Manajemen, VI(3), 333-348.

VISTA JUNITA. (2013). Pengaruh Brand Experience, Brand Commitment Dan Brand Loyalty Terhadap Keputusan Pembelian Apple Iphone Di Mitra Anda Cell Tegal Dan Erafone Megastore Pacific Mall Tegal. Journal of Chemical Information and Modeling, 53(9), 16891699.

Yobeanto, K. L. (2020). Pengaruh Brand Experience Melalui Customer Satisfaction Dan Brand Trust Terhadap Brand Loyalty Pada Merek Smartphone Samsung. Agora, 8(2). 